\title{
THE ROLE OF MEDICAL COMMITTEE FOR THE ACHIEVEMENT OF GOOD CLINICAL GOVERNANCE AT DELI SERDANG HOSPITAL, NORTH SUMATERA
}

\author{
Ratna Wulandari, Zulfendri, Surya Utama \\ Masters Program in Public Health, Faculty of Public Health, \\ Universitas Sumatera Utara
}

\begin{abstract}
Background: Clinical governance is defined as the framework through which health care organizations are accountable for continuously improving the quality of their services and safeguarding high standards of care by creating an environment in which excellence in clinical care will flourish. It places a responsibility on the board, and also the medical committee. This study aimed to investigate the role of medical committee for the achievement of good clinical governance at Deli Serdang Hospital, North Sumatera.

Subjects and Method: This was qualitative study carried out at Deli Serdang Hospital, North Sumatera. A sample of informants were selected for this study by purposive sampling, consisting of medical committee members, hospital managers, medical doctors, other health professionals, and a few patients. The dependent variable was the achievement of good clinical governance. The independent variable was the role of medical committee. The data were collected by in-depth interview, focus group discussion, document review, and analyzed by thematic analysis.

Results: The clinical governance had not been well implemented at Deli Serdang Hospital, North Sumatera. The medical committee had not functioned according to the Ministry of Health Regulation Number 755/MENKES/PER/IV/2011 on the role of medical committee at the hospital. This slow progress arose due to the lack of planning and budgeting being made to support the functioning of the medical committee.

Conclusion: The clinical governance has not been well implemented at Deli Serdang Hospital, North Sumatera. There is a need to conduct planning and budgeting to allow the functioning of the medical committee.
\end{abstract}

Keywords: medical committee, clinical governance, hospital

\section{Correspondence:}

Ratna Wulandari. Masters Program in Public Health, Faculty of Public Health, Universitas Sumatera Utara, Medan, North Sumatera.

Email: ratnawulandari.dr@gmail.com. Mobile: 085216006107. 